\section{Calcium Influences Growth and Leaf Mineral Concentration of Citrus under Saline Conditions}

\author{
Mongi Zekri and Lawrence R. Parsons \\ Citrus Research and Education Center, Institute of Food and Agricultural \\ Sciences, University of Florida, 700 Experiment Station Road, Lake \\ Alfred, FL 33850
}

Additional index words. Citrus aurantium, calcium sulfate, sodium chloride, root growth, shoot growth, sour orange

\begin{abstract}
We determined whether the ability of sour orange seedlings to withstand saline irrigation water could be improved by the addition of calcium to the water. Sour orange (Citrus aurantium L.) seedlings were treated for 4 months with a nutrient solution containing either no $\mathrm{NaCl}, 40 \mathrm{~mm} \mathrm{NaCI}$, or $40 \mathrm{~mm} \mathrm{NaCl}$ plus various concentrations of $\mathrm{CaSO}_{4}, \mathrm{CaCl}_{2}$, or $\mathrm{KCl}$. After 4 months, the $\mathrm{NaCl}$ alone reduced root and shoot dry weights by $\approx 30 \%$ with no leaf necrosis. Addition of 1,5 , or $7.5 \mathrm{~mm} \mathrm{CaSO}_{4}$ to solutions containing $40 \mathrm{~mm} \mathrm{NaCl}$ significantly inhibited the $\mathrm{NaCl}$-induced reductions in shoot dry weight. Addition of $7.5 \mathrm{~mm} \mathrm{CaCl}_{2}$ or $7 \mathrm{~mm} \mathrm{KCl}$ to the $\mathrm{NaCl}$ solution reduced leaf $\mathrm{Na}$, but increased $\mathrm{Cl}$ to the toxicity level; hence, growth was not improved. The beneficial effect of $\mathrm{CaSO}_{4}$ was mainly attributed to a reduction in the accumulation of $\mathrm{Na}$ and $\mathrm{Cl}$ below the toxicity level in the leaves $(0.4 \%$ and $0.5 \%$, respectively) without a major increase in total dissolved salts. This study demonstrated that the beneficial effect of adding $\mathrm{Ca}$ depended on the anion associated with the Ca salt. Calcium sulfate, but not $\mathrm{CaCl}_{2}$, was able to overcome the damaging effect of $\mathrm{NaCl}$ to sour orange seedlings.
\end{abstract}

Salts in soil and irrigation water are a serious problem for commercial agriculture, particularly in arid and semi-arid regions. However, the potential for salinity damage also exists in humid climates. Citrus productivity in some humid areas is threatened because only saline water is available for irrigation. Citrus has relatively little salt tolerance (Cooper, 1961).

In Florida, many citrus plantings are located in coastal areas where high-salinity waters are being used for irrigation (Calvert and Reitz, 1965; Wander and Reitz, 1951; Young and Jamison, 1944). Citrus plantings in these and other southern Florida areas have increased in response to extensive freeze damage that occurred in the early 1980s in northern and central Florida. This shift in citrus production regions has created an interest in controlling or reducing salt injury to Florida citrus.

Calcium has been shown to ameliorate the effect of saline conditions on the growth of plants (Deo and Kanwar, 1969; Epstein, 1972; Hyder and Greenway, 1965). This effect has been attributed to several actions of $\mathrm{Ca}$, including: 1) flocculation of the soil in which clay particles have been dispersed by $\mathrm{Na}$ (Richards, 1954), 2) preventing the uptake of the $\mathrm{Na}$ ion to injurious levels and allowing the uptake of K (Waisel, 1962), and 3) maintaining the selective permeability of mem-

Received for publication 13 July 1989.' Florida Agricultural Experiment Station, Journal Series no. R-00020. The cost of publishing this paper was defrayed in part by the payment of page charges. Under postal regulations, this paper therefore mus be hereby marked advertisement solely to indicate this fact. 40 mм.)

${ }^{2} \mathrm{TDS}=$ total dissolved salts.

${ }^{y} \mathrm{EC}=$ electrical conductivity. study because it is a popular rootstock in both Florida and other parts of the world.

Uniform, 3-month-old sour orange seedlings were transplanted into $19-\mathrm{cm}$-tall black plastic pots containing 5.5 liters of fine sand taken from the top $30 \mathrm{~cm}$ of a citrus orchard soil. The soil was Astatula fine sand (hyperthermic, uncoated Typic Quartzipsamments), with a $\mathrm{pH}$ of 6.5 and field capacity and wilting percentage of $7.2 \%$ and $1.2 \%$ (volumetric basis), respectively. Seedlings were placed in a greenhouse and irrigated every 2 to 3 days with a modified half-strength Hoagland's solution for 1 month before salt treatments were started. The temperature and relative humidity in the greenhouse ranged from 20 to $35 \mathrm{C}$ and from $40 \%$ to $100 \%$, respectively. Salt treatments were initiated by adding $40 \mathrm{~mm} \mathrm{NaCl}$ to the half-strength Hoagland's solution and by- also adding $\mathrm{CaSO}_{4}, \mathrm{CaCl}_{2}$, or $\mathrm{KCl}$ to selected treatments (Table 1). Due to other ions, the total dissolved salts (TDS) of the control half-strength Hoagland's solution was 0.4 g.liter ${ }^{-1}$, even though no $\mathrm{NaCl}$ was added to it.

Each treatment was replicated eight times in a randomized complete-block design. The osmotic potentials of the salt solutions were measured with a vapor pressure osmometer. Electrical conductivities of the treatments were determined with a conductivity meter (YSI Model 33; YSI, Yellow Springs, Ohio). Electrical conductivity values were converted to TDS (Richards, 1954). Seedlings were irrigated with the various solutions every 2 to 3 days for 4 months. The amount of solution added with each irrigation was determined by bringing the soil in the containers to slightly above water-holding capacity to prevent salt accumulation in the growth medium and to prevent plants from being drought stressed.

Seedlings were harvested after 4 months of experimental treatments. Dry weights of leaves, stems, and roots were measured after 3 days of drying at $60 \mathrm{C}$. The dried leaves, which had been mature and fully expanded, were ground and their mineral concentration was measured. Leaf $\mathrm{Cl}$ content was determined by silver ion titration with a BuchlerCotlove chloridometer (Searle, Fort Lee, N.J.) after extracting the leaf samples with a 1 nitric acid : 16 acetic acid (v/v) solution. Leaf $\mathrm{Ca}, \mathrm{Mg}, \mathrm{Na}, \mathrm{K}, \mathrm{P}, \mathrm{Fe}, \mathrm{Mn}, \mathrm{Zn}$, and $\mathrm{Cu}$ concentrations were measured by an inductively coupled argon plasma emission

Table 1. Salt additions to and physical properties of the nutrient solutions. $(\mathrm{NaCl}$ concentration was

\begin{tabular}{|c|c|c|c|}
\hline Treatment & $\begin{array}{c}\text { TDS }^{2} \\
\left(\mathrm{~g} \cdot \text { liter }^{-1}\right)\end{array}$ & $\begin{array}{c}E C^{y} \\
\left(\mathrm{dS} \cdot \mathrm{m}^{-1}\right)\end{array}$ & $\begin{array}{c}\text { Osmotic } \\
\text { potential } \\
(\mathrm{MPa})\end{array}$ \\
\hline Control (no $\mathrm{NaCl}$ ) & 0.4 & 0.9 & -0.03 \\
\hline $\mathrm{NaCl}$ & 2.8 & 5.0 & -0.19 \\
\hline $\mathrm{NaCl}+1 \mathrm{~mm} \mathrm{CaSO}_{4}$ & 2.9 & 5.2 & -0.19 \\
\hline $\mathrm{NaCl}+5 \mathrm{~mm} \mathrm{CaSO}_{4}$ & 3.1 & 5.5 & -0.21 \\
\hline $\mathrm{NaCl}+7.5 \mathrm{~mm} \mathrm{CaSO}_{4}$ & 3.5 & 6.3 & -0.23 \\
\hline $\mathrm{NaCl}+13.5 \mathrm{~mm} \mathrm{CaSO}_{4}$ & 3.8 & 6.8 & -0.26 \\
\hline $\mathrm{NaCl}+7.5 \mathrm{mM} \mathrm{CaCl}_{2}$ & 3.6 & 6.5 & -0.24 \\
\hline $\mathrm{NaCl}+7 \mathrm{~mm} \mathrm{KCl}$ & 3.4 & 6.1 & -0.23 \\
\hline
\end{tabular}



walk, Corm.) after a wet digestion of the samples with a 4 nitric acid : 1 perchloric acid (v/v) mixture.

Analysis of variance was used to determine significant differences, and Duncan's multiple range test was used for mean comparison when $\mathrm{F}$ test was significant at $P<$ 0.05 .

Shoot dry weight was significantly reduced (by early 30\%) when $40 \mathrm{~mm} \mathrm{NaCl}$ was added, to the nutrient solution (Table 2). Although dot significant, the percentage reduction in root dry weight for each treatment was nearly the same as for shoot. We attribute this lack of significance to variation addition of 1,5 , or 7.5 , but not 13.5 , mM $\mathrm{CaSO}_{4}$ to the saline solution significantly decreased the adverse effect of $\mathrm{NaCl}$ on shoot growth. Lack of improvement for $13.5 \mathrm{~mm}$ $\mathrm{CaSO}_{4}$ could be attributed to an increase in the osmotic stress (lower osmotic potential and higher TDS) of the salt solution (Table 1). Addition of either $\mathrm{CaCl}_{2}$ or $\mathrm{KCl}$ to the saline solution did not improve. shoot growth relative to $\mathrm{NaCl}$ alone.

Addition of $\mathrm{NaCl}$ alone to the nutrient solution significantly increased leaf $\mathrm{Na}$ and $\mathrm{Cl}$, but decreased $\mathrm{Ca}, \mathrm{Mg}$, and $\mathrm{K}$ (Table 3). Leaf $\mathrm{Na}$ and $\mathrm{Cl}$ accumulation above $0.4 \%$ and $0.5 \%$, respectively, usually reduced citrus seedling growth (Zekri, 1987). Addition of $\mathrm{CaSO}_{4}$ to the saline solution reduced $\mathrm{Na}$ and $\mathrm{Cl}$ concentrations, except that $1 \mathrm{~mm}$ did not reduce $\mathrm{Na}$ concentration. Addition of $\mathrm{CaCl}_{2}$ reduced $\mathrm{Na}$ but increased $\mathrm{Cl}$ to the toxicity level $(>0.5 \%)$ in the leaves. Addition of $\mathrm{KCl}$ did not reduce $\mathrm{Na}$, increased $\mathrm{Cl}$, and reduced spectrometer (Perkin-Elmer Plasma 40, Norin root dry weight among replications. The

$\mathrm{Ca}$ and $\mathrm{Mg}$ relative to $\mathrm{NaCl}$ alone. No significant differences in $\mathrm{P}, \mathrm{Fe}, \mathrm{Mn}, \mathrm{Zn}$, and $\mathrm{Cu}$ were found among the treatments (data not shown).

Growth was reduced significantly without any visible leaf symptoms of salt damage. Although root and shoot dry weights were reduced by nearly $30 \%$ in some treatments after 4 months of salinity stress, none of these treatments induced visible bum or other damage symptoms on leaves.

Under saline conditions, the addition of $\mathrm{Ca}$ to irrigation waters altered sour orange seedling response. This study showed that the beneficial effect of $\mathrm{Ca}$ depended on the anion associated with the $\mathrm{Ca}$. Calcium sulfate was significantly more effective than $\mathrm{CaCl}_{2}$ in reducing the deleterious effect of $\mathrm{NaCl}$ on shoot growth (Table 2). Walker and Douglas (1983) also did not observe any improvement in citrus growth by increasing $\mathrm{CaCl}_{2}$ in the growth medium. However, earlier work on citrus demonstrated the effectiveness of $\mathrm{CaSO}_{4}, \mathrm{CaNO}_{3}$, and $\mathrm{CaCO}_{3}$ on reducing $\mathrm{Na}$ concentration in citrus leaf tissue (Jones et al., 1952), on preventing the soil deflocculation effect of $\mathrm{Na}$, and on improving tree appearance (Cooper, 1961; Harding et al., 1958). LaHaye and Epstein $(1969,1971)$ demonstrated that an increase in $\mathrm{Ca}$ levels by adding either $\mathrm{CaSO}_{4}$ or $\mathrm{CaCl}_{2}$ protected bean plants from salt injury by restricting $\mathrm{Na}$ absorption and translocation to the leaves. Failure in the effectiveness of $\mathrm{CaC}_{2}$ in our work might have been due to the $\mathrm{Cl}$ accompanying the $\mathrm{Ca}$ and to the sensitivity of citrus to $\mathrm{Cl}$.

Sodium chloride significantly reduced growth of Leucaena leucocephala; however,

Table 2. Root and shoot dry weights of sour orange seedlings after 4 months of treatment with salt solutions. ${ }^{2} \mathrm{NaCI}$ concentration was $40 \mathrm{~mm}$.)

\begin{tabular}{|c|c|c|c|c|}
\hline \multirow[b]{2}{*}{ Treatment } & \multicolumn{2}{|c|}{ Root dry wt } & \multicolumn{2}{|c|}{ Shoot dry wt } \\
\hline & $\begin{array}{c}\text { Mean } \\
\text { actual } \\
(\mathrm{g})\end{array}$ & $\begin{array}{c}\text { Relative } \\
(\%)\end{array}$ & $\begin{array}{c}\text { Mean } \\
\text { actual } \\
(\mathrm{g})\end{array}$ & $\begin{array}{c}\text { Relative } \\
(\%)\end{array}$ \\
\hline Control (no $\mathrm{NaCl}$ ) & $9.4 \mathrm{a}$ & 100 & $36.6 \mathrm{a}$ & 100 \\
\hline $\mathrm{NaCl}$ & $6.8 \mathrm{a}$ & 72 & $25.9 \mathrm{~d}$ & 71 \\
\hline $\mathrm{NaCl}+1 \mathrm{mMCaSO}_{4}$ & $8.2 \mathrm{a}$ & 87 & $32.2 \mathrm{ab}-$ & 88 \\
\hline $\mathrm{NaCl}+5 \mathrm{~mm} \mathrm{CaSO}_{4}$ & $9.3 \mathrm{a}$ & 99 & $37.0 \mathrm{a}$ & 101 \\
\hline $\mathrm{NaCl}+7.5 \mathrm{~mm} \mathrm{CaSO}_{4}$ & $9.2 \mathrm{a}$ & 97 & $33.4 \mathrm{ab}$ & 91 \\
\hline $\mathrm{NaCl}+13.5 \mathrm{mM} \mathrm{CaSO}_{4}$ & $7.5 \mathrm{a}$ & 80 & $29.2 \mathrm{bcd}$ & 80 \\
\hline $\mathrm{NaCl}+7.5 \mathrm{mM} \mathrm{CaCl}_{2}$ & $7.5 \mathrm{a}$ & 79 & $28.4 \mathrm{~cd}$ & 78 \\
\hline $\mathrm{NaCl}+7 \mathrm{~mm} \mathrm{KCl}$ & $6.9 \mathrm{a}$ & 73 & $27.0 \mathrm{~cd}$ & 74 \\
\hline
\end{tabular}

${ }^{2}$ Mean of eight replications; mean separation within columns by Duncan's multiple range test, $P=$ 0.05 .

Table 3. Leaf mineral concentration (percent leaf dry weight) of sour orange seedlings after 4 months of treatment with salt solutions. ${ }^{2}(\mathrm{NaCl}$ concentration was $40 \mathrm{~mm})$

\begin{tabular}{|c|c|c|c|c|c|}
\hline \multirow[b]{2}{*}{ Treatment } & \multicolumn{5}{|c|}{ Mineral content $(\%)$} \\
\hline & $\mathrm{Ca}$ & $\mathrm{Mg}$ & $\mathrm{Na}$ & $\mathrm{cl}$ & $\mathrm{K}$ \\
\hline Control (no $\mathrm{NaCl}$ ) & $2.1 \mathrm{~b}$ & $0.30 \mathrm{a}$ & $0.02 \mathrm{c}$ & $0.02 \mathrm{~d}$ & $2.8 \mathrm{~b}$ \\
\hline $\mathrm{NaCl}$ & $1.7 \mathrm{c}$ & $0.21 \mathrm{~b}$ & $0.47 \mathrm{a}$ & $0.97 \mathrm{~b}$ & $2.0 \mathrm{c}$ \\
\hline $\mathrm{NaCl}+1 \mathrm{~mm} \mathrm{CaSO}_{4}$ & $1.7 \mathrm{c}$ & $0.22 \mathrm{~b}$ & $0.43 \mathrm{a}$ & $0.48 \mathrm{c}$ & $2.1 \mathrm{c}$ \\
\hline $\mathrm{NaCl}+5 \mathrm{mM} \mathrm{CaSO}_{4}$ & $2.4 \mathrm{ab}$ & $0.21 \mathrm{~b}$ & $0.27 \mathrm{~b}$ & $0.41 \mathrm{c}$ & $1.9 \mathrm{c}$ \\
\hline $\mathrm{NaCl}+7.5 \mathrm{~mm} \mathrm{CaSO}_{4}$ & $2.7 \mathrm{a}$ & $0.20 \mathrm{~b}$ & $0.24 \mathrm{~b}$ & $0.43 \mathrm{c}$ & $1.9 \mathrm{c}$ \\
\hline $\mathrm{NaCl}+13.5 \mathrm{~mm} \mathrm{CaSO}_{4}$ & $2.7 \mathrm{a}$ & $0.20 \mathrm{~b}$ & $0.24 \mathrm{~b}$ & $0.39 \mathrm{c}$ & $1.9 \mathrm{c}$ \\
\hline $\mathrm{NaCl}+7.5 \mathrm{mM} \mathrm{CaCl}_{2}$ & $2.8 \mathrm{a}$ & $0.20 \mathrm{~b}$ & $0.25 \mathrm{~b}$ & $1.36 \mathrm{a}$ & $2.0 \mathrm{c}$ \\
\hline $\mathrm{NaCl}+7 \mathrm{~mm} \mathrm{KCl}$ & $1.3 \mathrm{~d}$ & $0.15 \mathrm{c}$ & $0.43 \mathrm{a}$ & $1.21 \mathrm{a}$ & $3.6 \mathrm{a}$ \\
\hline
\end{tabular}

${ }^{2}$ Mean of eight replications; mean separation within columns by Duncan's multiple range test, $P=$ 0.05 . additions of $\mathrm{CaSO}_{4}$ increased plant height, leaf number, and biomass of salt-treated plants (Hansen and Munns, 1988b). While high Na concentrations produced a $\mathrm{Ca}$ deficiency in cotton seedlings, supplemental $\mathrm{Ca}$ counteracted the toxic effect of $\mathrm{NaCl}$ and restored growth (Kent and Läuchli, 1985).

Calcium concentrations in external solutions that are adequate under nonsaline conditions become inadequate when the external $\mathrm{Na}$ : Ca ratio is high (Bernstein, 1975). This extra $\mathrm{Ca}$ is required to counteract the adverse effects of toxic ions in the external solution on plant growth. Bernstein also found plant response to salinity to be a function not only of the total salt concentration but also of the $\mathrm{Na}$ : $\mathrm{Ca}$ ratio in the root medium. Grieve and Maas (1988) demonstrated the sensitivity of sorghum to the $\mathrm{Na}: \mathrm{Ca}$ ratio in saline root media. The reduction in the $\mathrm{Na}: \mathrm{Ca}$ ratio in the external solution through the addition of Ca significantly decreased leaf $\mathrm{Na}$ concentration and increased shoot growth of beans (LaHaye and Epstein, 1969, 1971) and rice (Muhammed et al., 1987). Sodium-Ca interactions can also occur within the plant. Zid and Grignon (1985) concluded that the main ionic disturbance in leaves of Citrus aurantium plants grown in the presence of $\mathrm{NaCl}$ was a competition between $\mathrm{Na}$ and $\mathrm{Ca}$ for anionic sites in the cell walls. They suggested that this phenomenon could be one of the causes of necrotic burns that are characteristic of $\mathrm{Na}$ toxicity due to $\mathrm{Na}$ accumulation and $\mathrm{Ca}$ displacement in the leaf free space.

In our study, $\mathrm{NaCl}$ reduced shoot growth due partially to excess accumulation of $\mathrm{Na}$ and $\mathrm{Cl}$ in the leaves. The improvement of shoot growth by addition of $\mathrm{CaSO}_{4}$ likely was not totally due to the effect of $\mathrm{Ca}$ in maintaining the selective permeability of membranes, because shoot growth was not improved by addition of $\mathrm{CaCl}_{2}$. We believe that the competitive interaction between $\mathrm{Ca}$ and $\mathrm{Na}$ and between $\mathrm{SO}_{4}$ and $\mathrm{Cl}$ contributed to offsetting the deleterious effect of $\mathrm{NaCl}$ on citrus growth. We also believe that addition of $\mathrm{CaSO}_{4}$ to the saline solution decreased both the $\mathrm{Na}$ : $\mathrm{Ca}$ and $\mathrm{Cl}: \mathrm{SO}_{4}$ ratios in the medium. Hence, there would be less $\mathrm{Na}$ and $\mathrm{Cl}$ uptake and accumulation in the leaves, where these ions can disturb metabolic processes.

In conclusion, this study demonstrated that $\mathrm{CaSO}_{4}$ improved the ability of sour orange to tolerate salt and that the beneficial effect of adding $\mathrm{Ca}$ to saline irrigation water depended on the anion accompanying the $\mathrm{Ca}$. Calcium sulfate, but neither $\mathrm{CaCl}_{2}$ nor $\mathrm{KCl}$, was found to overcome the detrimental effects of $\mathrm{NaCl}$ by decreasing the concentrations of $\mathrm{Na}$ and $\mathrm{Cl}$ in citrus leaves.

\section{Literature Cited}

Bernstein, L. 1975. Effect of salinity and sodicity on plant growth. Annu. Rev. Phytopathol. 13:295-312.

Calvert, D.V. and H.J. Reitz. 1965. Salinity of water for sprinkle irrigation of citrus. Proc. Fla. State Hort. Soc. 78:73-78.

Cooper, W.C. 1961. Toxicity and accumulation 
of salts in citrus trees on various rootstock in Texas. Proc. Fla. State Hort. Soc. 74:95-104.

Dee, R. and J.S. Kanwar. 1969. Effect of saline irrigation waters on the growth and chemical composition of wheat. J. Indian soc. Soil Sci. 16:365-370.

Epstein, E. 1972. Mineral nutrition of plants. Principles and perspectives. Wiley, New 'York.

Grieve, C.M. and E.V. Maas. 1988. Differential effects of sodium/calcium ratio on sorghum genotypes. Crop Sci. 28:659-665.

Hansen, E.H. and D.N. Munns. 1988a. Effect of $\mathrm{CaSO}_{4}$ and $\mathrm{NaCl}$ on mineral content of $\mathrm{Leu}$ caena leucocephala. Plant \& Soil 107:101-105.

Hansen, E. H.. and D.N. Munns. 1988b. Effects of $\mathrm{CaSO}_{4}$ and $\mathrm{NaCl}$ on growth and nitrogen fixation of Leucaena leucocephalo. Plant \& Soil 107:95-99.

Harding, R. B., P.F. Pratt, and W.W. Jones. 1958. Changes in salinity, nitrogen, and soil reaction in a differentially fertilized irrigated soil. Soil Sci. 85:177-184.

Hyder, S.Z. and H. Greenway. 1965. Effects of $\mathrm{Ca}^{++}$on plant sensitivity to high $\mathrm{NaCl}$ concentrations. Plant \& Soil 23:258-260.

Jones, W. W., H.E. Pearson, E.R. Parker, and M.R. Huberty. 1952. Effect of sodium in fertilizer and in irrigation water on concentration in leaf and root tissues of citrus trees. Proc. Amer. Soc. Hort. Sci. 60:65-70.

Kawasaki, T., G. Shimizu, and M. Moritsugu. 1983. Effects of high concentrations of sodium chloride and polyethylene glycol on the growth and ion absorption in plants. II. Multi-compartment transport box experiment with excised roots of barley. Plant \& Soil 75:87-93.

Kent, L.M. and A. Läuchli. 1985. Germination and seedling growth of cotton: Salinity-calcium interactions. Plant, Cell \& Environ. 8: 155-159.

LaHaye, P.A. and E. Epstein. 1969. Salt toleration by plants: Enhancement with calcium. Science 166:395-396.

LaHaye, P.A. and E. Epstein. 1971. Calcium and salt toleration by bean plants. Physiol. Plant. 25:213-218.

Muhammed, S., M. Akbar, and H.U. Neue. 1987. Effect of $\mathrm{Na} / \mathrm{Ca}$ and $\mathrm{Na} / \mathrm{K}$ ratios in saline culture solution on the growth and mineral nutrition of rice (Oryzu sativa L.). Plant \& Soil 104:57-62.

Pearson, H.E and M.R. Huberty 1959. Response of citrus to irrigation with water of different chemical-characteristics. Proc. Amer. Soc. Hort. Sci. 73:248-256.

Richards, L.A. 1954. In: Diagnosis and improvement of saline and alkali soils. USDA Agr. Hdbk. 60. D. 4-5.

Waisel, Y. 1962. The effect of Ca on the uptake of monovalent ions by excised barley roots. Physiol. Plant. 15:709-724

Walker, R.R. and T.J. Douglas. 1983. Effect of salinity level on uptake and distribution of chloride, sodium and potassium ions in citrus plants. Austral. J. Agr. Res. 34:145-153.

Wander, I.W. and H.J. Reitz. 1951. The chemical composition of irrigation water used in Florida citrus groves. Fla. Agr. Expt. Sta. Bul. 480.

Young, T.W. and V.C. Jamison. 1944. Saltiness in irrigation wells. Fla. State Hort. Soc. 57: 1823.

Zekri, M. 1987. Effects-of sodium chloride and polyethylene glycol on the water relations, growth, and morphology of citrus rootstock seedlings. PhD Diss., Univ. of Florida, Gainesville. (Diss. Abstr. 88-18542).

Zid, E. and C. Grignon. 1985. Sodium-calcium interactions in leaves of Citrus aurantium grown in the presence of NaC1. Physiol. Veg. 23 :895903. 